\title{
Erratum to: Legitimacy of Inequality in a Highly Unequal Context: Evidence from the Chilean Case
}

\author{
Juan Carlos Castillo
}

Published online: 14 January 2012

(C) Springer Science+Business Media, LLC 2012

Erratum to: Soc Just Res (2011) 24:314-340

DOI 10.1007/s11211-011-0144-5

Unfortunately, the address of author's institution is incorrect in the online and print version of the original article. The address has been corrected in this article.

The online version of the original article can be found under doi:10.1007/s11211-011-0144-5.

J. C. Castillo ( $\bowtie)$

Faculty of Social Sciences, Pontificia Universidad Católica de Chile,

Vicuña Mackenna 4860, 7820436 Macul, Santiago, Chile

e-mail: jcastillov@puc.cl 